JOTE Volume 2 Nomor 1 Tahun 2020 Halaman 156-166 JOURNAL ON TEACHER EDUCATION

Research \& Learning in Faculty of Education

\title{
UPAYA MENINGKATKAN KEMAMPUAN GURU SDI WAIRHEK DALAM MENYUSUN RPP TEMATIK MELALUI SUPERVISI AKADEMIK PADA SEMESTER I TAHUN PELAJARAN 2018/2019
}

\author{
Linus \\ SDI Wairhek Kecamatan Talibura Kabupaten Sikka \\ Email : linus@gmail.com
}

\begin{abstract}
Abstrak
Penelitian Tindakan sekolah ini bertujuan untuk meningkatkan kemampuan guru SDI Wairhek Kecamatan Talibura Kabupaten Sikka dalam menyusun RPP tematik melalui supervisi akademik. Penelitian menujukkan bahwa supervisi akademik secara kelompok pada siklus I, diperoleh data guru-guru belum mengikuti prosedur penyunan RPP tematik dengan benar dan RPP yang disusun oleh guru SDI Wairhek masih belum maksimal, maka perlu dilakukan supervisi akademik lanjutan yaitu pada siklus II. Hasil penelitian rata-rata (1) Kemampuan guru kelas SDI Wairhek Kecamatan Talibura Kabupaten Sikka, dalam mengikuti prosedur menyusun RPP tematik meningkat dari kondisi awal sebesar 29,17\% (kategori sangat kurang) menjadi 68,75\% (kategori cukup) diakhir siklus I dan menjadi $84,38 \%$ diakhir siklus II. Dan, (2) Kemampuan guru kelas SDI Wairhek dalam menyusun RPP tematik meningkat dari kondisi awal 57,74 (kategori Cukup) menjadi 75,00 (dengan kriteria Baik), dan meningkat menjadi 89,29 diakhir siklus II.
\end{abstract}

Kata kunci: Kemampuan Guru, RPP Tematik, Suvervisi Akademik

\begin{abstract}
ability of SDI Wairhek teachers in Talibura District, Sikka Regency in preparing thematic lesson plans through academic supervision. Research shows that group academic supervision in cycle $\mathrm{I}$, it is obtained data that teachers have not followed the thematic lesson plan preparation procedures correctly and the lesson plans compiled by SDI Wairhek teachers are still not optimal, it is necessary to carry out further academic supervision, namely in cycle II. Average research results (1) The ability of SDI class teachers in Wairhek, Talibura District, Sikka Regency, in following the procedure of compiling thematic lesson plans increased from the initial condition of $29.17 \%$ (very poor category) to $68.75 \%$ (sufficient category) at the end of cycle I and becomes $84.38 \%$ at the end of cycle II. And, (2) The ability of SDI Wairhek class teachers in preparing thematic lesson plans increased from the initial condition 57.74 (Enough category) to 75.00 (with Good criteria), and increased to 89.29 at the end of cycle II.
\end{abstract}

Keywords: Teacher Ability, Thematic RPP, Academic Supervision 


\section{PENDAHULUAN}

Menurut Permendiknas Nomor 22 tahun 2016 dikatakan Proses pembelajaran diselenggarakan secara interaktif, menyenangkan, menantang, inspiratif, memotivasi peserta didik untuk berpartisipasi aktif, serta memberikan ruang yangcukup bagi prakarsa, kreatifitas, dan kemandirian sesuai dengan bakat, minat, kemampuan, dan perkembangan fisik serta psikologis peserta didik. Standar proses dikembangkan mencakup perencanaan proses pembelajaran, pelaksanaan proses pembelajaran, penilaian hasil pembelajaran, dan pengawasan proses pembelajaran. Inovasi guru di tingkat Sekolah Dasar (SD) sangat dibutuhkan dalam upaya merubah mindset guru dari pola pembelajaran yang mengarah ke guru sentris berbalik arak ke pola pembelajaran peserta didik aktif. Oleh karena itu, guru SD perlu menyiapkan Rencana Pelaksanaan Pembelajaran (RPP) tematik yang berorientasi pada peserta didik.

Menurut Peraturan Pemerintah Nomor 19 tahun 2005 pasal 20 dijelaskan bahwa perencanaan proses pembelajaran meliputi silabus dan rencana pelaksanaa pembelajaran (RPP). Dalam menyusun silabus seorang guru dituntut untuk mengembangkan KD yang ada dilengkapi dengan materi pokok pembelajaran, kegiatan pembelajaran, indikator, penilaian, alokasi waktu dan sumber belajar. Tahap-tahap yang perlu dilakukan adalah membuat pemetaan kompetensi dasar ke dalam indikator, kemudian menentukan tema, menetapkan jaringan tema, menyusun silabus, selanjutnya menyusun RPP tematik.

Kenyataan di lapangan guru kelas di SDI Wairhek melalui tahap tersebut di atas. Dari KD dan indikator, guru langsung membuat silabus dan RPP. RPP yang dibuat guru belum tematik masih terkotak-kotak dalam mata pelajaran. Tujuan pembelajaran belum disusun secara logis artinya belum disusun dari yang mudah ke yang sukar dan belum menunjukkan audience, behavior, condition dan degree. Pada kegiatan inti belum menunjukkan kegiatan eksplorasi, elaborasi dan konfirmasi, sehingga RPP tematik yang dibuat kurang bermakna. RPP tematik yang dibuat oleh guru kualitasnya masih rendah sehingga perlu ditingkatkan. Untuk mengatasi hal ini diperlukan supervisi terhadap guru oleh kepala sekolah. Supervisi yang dilakukan oleh kepala sekolah diatur dalam Permendiknas nomor 13 Tahun 2007 tentang Standar Kepala Sekolah/Madrasah. Kepala sekolah dalam kedudukannya sebagai supervisor berkewajiban membina para guru agar menjadi pendidik dan pengajar yang baik (LPPKS, 2014). Satu hal yang harus ditegaskan, bahwa setelah melakukan penilaian penampilan guru bukan berarti selesai tentang kegiatan supervisi, 
tetapi harus dilanjutkan dengan perancangan dan pelaksanaan pengembangan kemampuannya.

Untuk memecahkan masalah ini, maka peneliti melakukan penelitian tindakan sekolah dengan judul "Upaya Meningkatkan Kemampuan Guru SDI Wairhek Dalam Menyusun RPP Tematik Melalui Supervisi Akademik”. Penelitian dilakukan Pada Semester Ganjil Tahun Pelajarann 2018/2019. Hasil yang diharapkan melalui PTS ini adalah 1) apabila supervisi akademik dilaksanakan secara terencana, terjadwal dan konsisten maka kompetensi guru dalam menyusun RPP tematik yang dibuat oleh guru SDI Wairhek dapat ditingkatkan, 2) guru akan mengeluarkan jurus terbaiknya dalam melaksanakan proses pembelajaran di kelas senyatanya yang mengarah ke peserta didik aktif, inofatif, kreatif, efektif, dan menyenangkan (PAIKEM), 3) proses pembelajaran bisa berjalan efektif, dan menghasilkan produk peserta didik yang berkualitas

\section{METODE}

Lokasi yang digunakan dalam penelitian tindakan sekolah ini di SDI Wairhek kecamatan Talibura Kabupaten Sikka, yang terdiri dari 9 orang Guru, yang terdiri dari 6 orang guru berstatus PNS dan 3 orang guru Honor. 6 orang guru perempuan, 3 orang guru laki-laki. Terdapat 6 orang guru kelas, 2 orang guru Agama (guru agama Katholik dan guru Agama Islam), 1 orang guru PJOK. Penelitian dilaksanakan pada semester ganjil tahun pelajaran 2018/2019 dari bulan September sampai November 2018, dengan pertimbangan RPP yang sudah dibuat guru pada bulan Juli dan Agustus dapat digunakan untuk supervisi awal. Dalam pelaksanaan penelitian tindakan sekolah yang menjadi subjek yaitu semua guru kelas yang berjumlah 6 orang.

PTS ini dilaksanakan dalam dua siklus, dengan masing-masing siklus terdiri atas empat tahapan kegiatan yaitu tahap perencanaan, pelaksanaan, pengamatan, dan refleksi (Arikunto, 2011). Tahapan PTS digambarkan dalam diagram berikut: 


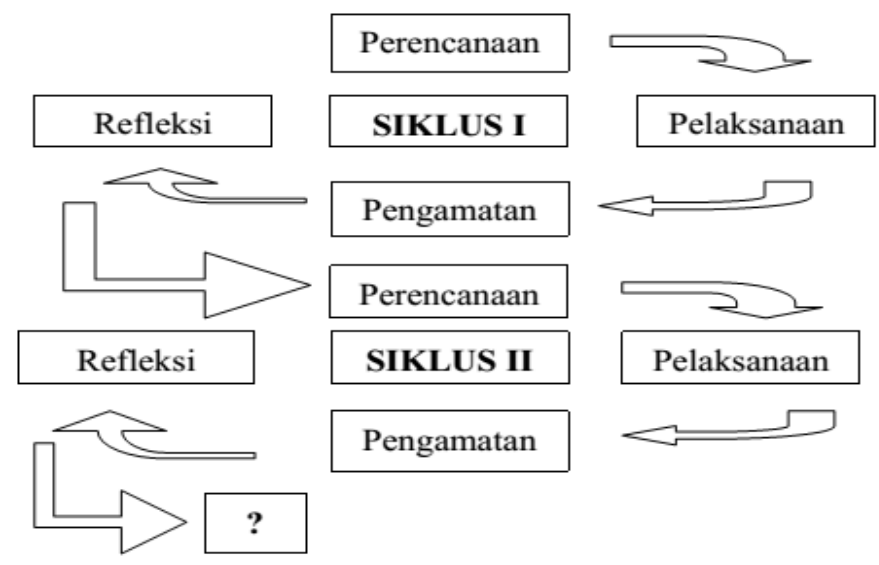

Gambar 1. Langkah-langkah PTS (Direktorat Tendik, 2008)

PTS dikatakan berhasil apabila rata-rata capaian masing-masing indikator pada tiap aspek $\geq 80 \%$. Komponen-komponen penelitian terdiri dari: 1) guru menguasai langkah-langkah menyusun RPP tematik, 2) Kemampuan guru dalam menyusun RPP tematik.

Data dalam PTS ini dikumpulkan dengan menggunakan berbagai instrumen penelitian (alat monitoring), seperti: catatan harian, lapangan, lembar observasi; pedoman wawancara; lembar angket/kuesioner, lembar masukan guru (refleksi tindakan); lembar penilaian unjuk kerja, dan hasil belajar siswa. Data yang telah terkumpul dalam penelitian ini selanjutnya dianalisis secara deskriptif. Analisis data difokuskan pada sasaran/variabel/objek yang akan diperbaiki/ ditingkatkan, misalnya tentang kesiapan guru dalam mengikuti bimbingan, frekuensi dan kualitas pertanyaan, cara menjawab dan penalarannya, kualitas kerjasama kelompok, aktivitas, partisipasi, motivasi, minat, konsep diri, berpikir kritis, kreativitas, kemandirian, dan lain-lain.

Data yang terkumpul dalam penelitian ini dianalisis secara kualitatif dan kuantitatif. Data kualitatif dianalisis dengan menggunakan analisis kategorial dan fungsional melalui model analisis interaktif (interactive model), yakni analisis yang dilakukan melalui empat komponen analisis: reduksi data, penyandian, dan verifikasi dilakukan secara simultan.

\section{Kondisi Pra Siklus}

Hasil supervisi akademik yang dilakukan sebelum tindakan penelitian diperoleh pada kondisi awal RPP tematik guru kelas di SDI wairhek masih rendah. Kemampuan guru dalam mengikuti Langkah-langkah penyusunan RPP tematik diperoleh data: 1) Menentukan Tema yang akan dikaji: hanya 2 orang dengan capaian 16,67\% termasuk kategori "Kurang", 2) Menentukan Tema yang sesuai dengan konsep-konsep yang ada dalam setiap KD: 3 orang dengan 
capaian 29,17\% termasuk kategori "Kurang", 3) menetapkan jaringan tema: hanya 3 orang yang membuat dengan capaian 54,17\% termasuk kategori "Kurang", 4) Mengembangkan Silabus: hanya 2 orang dengan capaian 16,67\% termasuk kategori "Kurang", dan 5) Menyusun RPP Tematik: Semua guru menmyusun RPP dengan capaian 54,17\% termasuk kategori "Kurang". Secara umum rata-rata guru yang menyusun $63,33 \%$ dengan capaian $39,17 \%$ termasuk kategori kurang.

Sedangkan Kemampuan guru dalam menyusun RPP diperoleh data: 1) Tujuan pembelajaran; capaian guru 62,50 dengan Kriteria Cukup, 2) Keakuratan materi pembelajaran; capaian guru 58,33 dengan Kriteria Cukup, 3) Kegiatan Pendahuluan; capaian guru 62,50 dengan Kriteria Cukup, 4) Kegiatan Inti; capaian guru 50,00 dengan Kriteria Kurang, 5) Kegiatan Penutup; capaian guru 58,33 dengan Kriteria Cukup, 6) Penilaian; capaian guru 58,33 dengan Kriteria Cukup, 7) Sumber Belajar; capaian guru 54,17 dengan Kriteria Kurang. Secara umum rata-rata guru yang menyusun $57,74 \%$ termasuk kategori Cukup. RPP yang dibuat guru sebagian besar belum terintegrasi dalam satu tema (tematik) dalam strategi mengajarnya masih ada batas / mencantumkan mata pelajaran sesuai jadwal hari itu.dan belum dilengkapi alokasi waktunya. Kegiatan siswa dan guru jelas Tujuan pembelajaran belum lengkap. Sebagian guru masih menggunakan RPP yang lama artinya belum tematik. Hasil yang rendah tersebut karena belum ada supervisi akademik dari kepala sekolahnya sebagai pendamping / motivator. Kepala sekolah belum mengadakan supervisi akademik secara terprogram baik secara kelompok maupun individu tentang RPP pembelajaran Tematik.

\section{Siklus I}

\section{1) Perencanaan}

Tindakan peneliti diawali dengan rapat internal sekolah SDI Wairhek kecamatan Talibura-Kabupaten Sikka dan teman sejawat (kolaborator) menyampaikan instrumen hasil penilaian RPP kondisi awal dan membahas rencana penelitian peningkatan kualitas RPP tematik. Selanjutnya menginformasikan kepada guru kelas dan teman sejawat untuk terlibat dalam penelitian ini sebagai kolaborator dan menjelaskan isi dan cara pengisian instrumen.

\section{2) Pelaksanaan}

Pelaksanaan tindakan pada siklus I ini peneliti mengadakan pertemuan membahas hasil supervisi bulan Juli dan Agustus. Kemudian menjelaskan 
tentang langkah-langkah penyusunan RPP tematik, dan bagaimana menyusun RPP tematik. Selanjutnya guru-guru diminta menyusun RPP sesuai penjelasan yang diberikan, dan diakhiri dengan mengadakan supervisi akademik. Peserta yang terdiri dari guru-guru kelas berjumlah 6 orang dan diobservasi kolaborator.

\section{3). Pengamatan}

Hasil supervisi dan pengamatan pada siklus 1, dapat disajikan sebagai berikut: (1). Kemampuan guru dalam mengikuti Langkah-langkah penyusunan RPP tematik Langkah-langkah penyusunan RPP tematikpada siklus I diperoleh data semua guru sudah melaksanakan langkah-langkah dalam menyusun RPP tematik, dengan capaian masing-masing komponen: 1) Menentukan Tema yang akan dikaji: capaian 66,67\% termasuk kategori "Cukup", 2) Menentukan Tema yang sesuai dengan konsep-konsep yang ada dalam setiap KD: capaian 70,83\% termasuk kategori "Cukup", 3) menetapkan jaringan tema: capaian 66,67\% termasuk kategori "cukup", 4) Mengembangkan Silabus: capaian 75,00\% termasuk kategori "Baik", dan 5) Menyusun RPP Tematik: capaian 62,50\% termasuk kategori "Cukup". Secara umum semua guru sudah menyusun RPP dengan mengikuti tahapan-tahapannya dengan capaian 68,33\% termasuk kategori "Cukup". (2). Kemampuan guru dalam menyusun RPP, hasil rata-rata kondisi siklus I diperoleh data capaian guru pada komponen: 1) Tujuan pembelajaran; 66,67 dengan Kriteria Cukup, 2) Keakuratan materi pembelajaran; capaian guru 70,83 dengan Kriteria Cukup, 3) Kegiatan Pendahuluan; capaian guru 79,17 dengan Kriteria Baik, 4) Kegiatan Inti; capaian guru 70,83 dengan Kriteria Cukup, 3) Kegiatan Penutup; capaian guru 87,50 dengan Kriteria Amat Baik, 6) Penilaian; capaian guru 75 dengan Kriteria baik, dan 7) Sumber Belajar; capaian guru 54,17 dengan Kriteria baik. Secara umum rata-rata guru menyusun $75 \%$ termasuk kategori Baik.

\section{4) Refleksi}

Dari kegiatan pada siklus I, dapat katakakan bahwa: 1) dari hasil pengamatan kolaborator: guru-guru cukup antusias dan semnagat dalam mendengarkan penjelasan, mengerjakan RPP tematik yang diminta. Guru berusaha bertanya kepada teman sejawat, kepada kepala sekolah maupun kolaborator. 2) dari hasil supervisi diperoleh perubahan yang signifikan dari kondisi pra siklus. Semua komponen dalam langkah-langkah menyusun RPP tematik dilaksnakan dengan baik oleh guru, dan mengalamai peningkatan secara siginifikan, dengan capaian rata-rata 68,33 (kategori cukup), meningkat sangat signifikan dari kondisi pra siklus 39,17 (kurang). Sedangkan capaian kemampuan 
guru dalam menyusun RPP terdapat komponen dengan capaian Amat Baik, yaitu kegiatan penutup pembelajaran, dan secara keseluruhan mencapai rata-rata 75,00 dengan kriteria Baik. Dari hasil pada siklus I, dijadikan bahan masukan untuk melengkapi dan menjadi fokus kegiatan pada siklus II.

\section{Siklus II}

\section{a) Perencanaan}

Menyampaikan hasil siklus I kepada guru kelas dan kolaborator. Kekurangan hasil pada siklus I ini ditindaklanjuti peneliti dengan merencanakan: (1) mendatangkan Nara Sumber dari Pengawas Satuan Pendidikan SD, (2) supervisi akademik secara individual (percakapan pribadi) langsung dengan guru kelas, untuk pembinaan secara individu tentang RPP tematik. Peneliti membantu memecahkan kesulitan yang dihadapi guru.

\section{b) Pelaksanaan}

Pelaksanaan siklus II dilakukan dengan pertama-tama: mendengarkan penjelasan Nara Sumber (Pengawas satuan pendidikan). Guru-guru diminta menyusun RPP tematik sesuai arahan tambahan dari nara sumber. Guru diberi kesempatan untuk menanyakan sampai sejelas-jelasnya tidak terikat waktu dengan harapan RPP tematik yang dibuat dalam siklus II lebih baik. Selanjutnya, peneliti melakukan wawancara secara individual (percakapan pribadi). Terakhir, Kepala sekolah (peneliti) dan teman sejawat (kolaborator) dilakukan supervisi akademik secara individu terhadap guru yang menyusun RPP tematik.

\section{3). Pengamatan}

Hasil supervisi dan pengamatan pada siklus II, dapat disajikan sebagai berikut: 1. Kemampuan guru dalam mengikuti Langkah-langkah penyusunan RPP tematik diperoleh data semua guru sudah melaksanakan langkah-langklah dalam menyusun RPP tematik, dengan capaian masing-masing komponen: ) Menentukan tema yang akan dikaji bersama siswa: 87,50\% termasuk kategori Amat baik, 2) Menentukan Tema yang sesuai dengan konsep-konsep yang ada dalam setiap KD: 87,50\% termasuk kategori Amat baik, 3) menetapkan jaringan tema: $79,17 \%$ termasuk kategori "Baik", 4) Mengembangkan Silabus: 79,17\% termasuk kategori "Baik" dan 5) Menyusun RPP Tematik: 83,33\% dengan kategori Baik. Secara umum semua guru (100\%) yang menyusun RPP tematik dengan capaian 83,33\% termasuk kategori "Baik". Sedangkan, 2. Kemampuan guru dalam menyusun RPP diperoleh data capaian guru pada komponen: 1) Tujuan pembelajaran; 95,83 dengan Kriteria Amat baik, 2) Keakuratan materi pembelajaran; capaian guru 87,50 dengan Kriteria Amat baik, 3) 
Kegiatan Pendahuluan; capaian guru 91,67 dengan Kriteria Amat baik, 4) Kegiatan Inti; capaian guru 83,33 dengan Kriteria Baik, 3) Kegiatan Penutup; capaian guru 91,67 dengan Kriteria Amat Baik, 6) Penilaian; capaian guru 83,33 dengan Kriteria baik, dan 7) Sumber Belajar; capaian guru 91,67 dengan Kriteria Amat baik. Secara umum rata-rata capaian kemampuan guru yang menyusun 89,29 termasuk kategori Amat Baik.

\section{4) Refleksi}

Dari kegiatan pada siklus II, dapat katakakan bahwa dengan mendatangkan nara sumber pengawas satuan pendidikan dan menjelaskan tentang RPP tematik, guru mengerjakan RPP tematik yang diminta, dan berusaha bertanya seluas-luasnya kepada nara sumber, diperoleh hasil perubahan yang signifikan dari kondisi siklus I. Pada siklus II, semua komponen dalam langkah-langkah menyusun RPP tematik dilaksnakan dengan baik oleh guru, dan mengalami peningkatan secara siginifikan, dengan capaian rata-rata 84,38 dengan kategori Baik, meningkat sangat signifikan dari kondisi siklus I 68,75. Sedangkan capaian kemampuan guru dalam menyusun RPP tematik terdapat 5 komponen dengan capaian Amat Baik, dan dua komponen mencapai kategori Baik. Secara keseluruhan mencapai rata-rata 89,29 dengan kriteria Amat Baik. Dari hasil pada siklus II, maka dikatakan peneltian telah berhasil dan dinyatakan selesai.

\section{PEMBAHASAN}

Pelaksanaan siklus I dilakukan setelah menganalisa data hasil supervisi akademik melalui instrumen supervisi akademik pra siklus. Tindakan penelitian dilakukan dimulai dengan memberikan bimbingan secara kelompok tentang penyusunan RPP tematik selama satu hari. RPP tematik yang telah disusun guru kelas pada siklus I tersebut kemudian diserahkan kepada kepala sekolah (peneliti). Hasil pada siklus I menunjukan kenaikan yang sangat signifikan: (1) mengikuti prosedur langkah-langkah dalam menyusun RPP tematik meningkat dibanding kondisi awal, yaitu dari 29, 17 (kategori sangat kurang) menjadi 68,75 (kategori cukup) pada akhir siklus I dengan kenaikan 39,58\%. (2) Kemampuan guru dalam menyusun RPP tematik mengalami peningkatan dari kondisi awal 57,74 (kategori Cukup) menjadi 75,00 (dengan kriteria Baik), atau terjadi peningkatan sebesar $17,26 \%$.

Setelah mengetahui masih adanya kekurangan pada RPP tematik yang disusun guru pada siklus I, selanjutnya peneliti mendatangkan Nara sumber dan melakukan supervisi akademik secara individu, agar RPP tematik yang disusun 
hasilnya lebih baik. Ternyata hasil pada siklus II, hasilnya lebih meningkat dibanding lagi pada siklus I, yaitu: (1) kemampuan guru mengikuti prosedur langkah-langkah dalam menyusun RPP tematik meningkat dibanding kondisi siklus I, yaitu dari 68,75 (kategori cukup) pada akhir siklus I mengalami peningkatan pada akhir siklus II menjadi 84,38 dengan kenaikan sebesar 15,63\%. Dan, (2) Kemampuan guru dalam menyusun RPP tematik mengalami peningkatan dari kondisi siklus I 774 (kategori Cukup) menjadi 75,00 (dengan kriteria Baik), atau terjadi peningkatan sebesar $14,29 \%$ pada akhir siklus II. Supervisi akademik secara individu ternyata lebih efektif dibanding supervisi kelompok.

Oleh karena indikator keberhasilan sudah dapat tercapai (>80\%) maka penelitian Tindakan Sekolah (PTS) dengan judul: "Upaya Meningkatkan Kemampuan Guru SDI Wairhek Dalam Menyusun Rpp Tematik Melalui Supervisi Akademik dinyatakan "BERHASIL" dan dapat dihentikan pada siklus ke II. Keberhasilan ini merupakan bukti nyata bahwa pelaksanaan supervisi akademik di SDI Wairhek Kecamatan Talibura Kabupaten Sikka pada semester ganjil tahun pelajaran 2018/2019 dapat meningkatan kemampuan guru kelas dalam menyusun RPP tematik.

Tabel 1. Peningkatan Kompetensi Guru SDI Wairhek Tiap Siklus

\begin{tabular}{lccc}
\hline \multicolumn{1}{c}{ Kompetensi Paedagogik } & Pra Siklus & Siklus I & Sikuls II \\
\hline $\begin{array}{l}\text { Kemampuan guru mengikuti } \\
\text { prosedur penyusunan RPP } \\
\text { tematik }\end{array}$ & 29,17 & 68,75 & 84,38 \\
\hline $\begin{array}{l}\text { Kemampuan guru dalam } \\
\text { menyusun RPP tematik }\end{array}$ & 57,74 & 75,00 & 89,29 \\
\hline
\end{tabular}

Disajikan dengan diagram batang berikut ini:

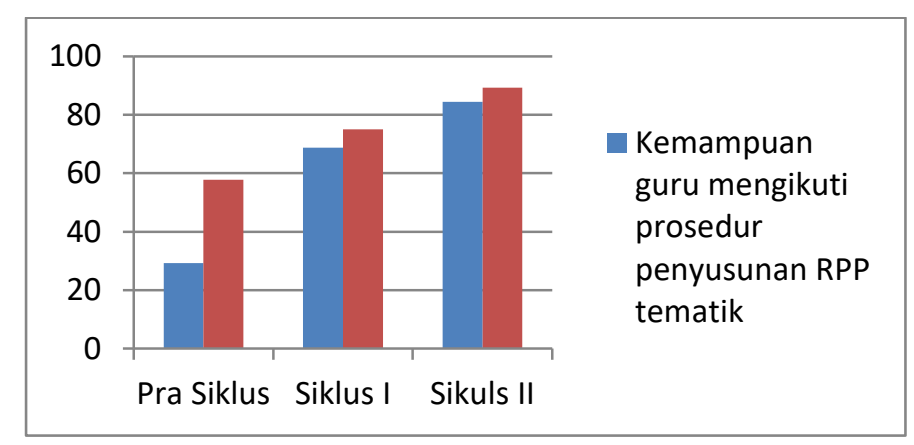

Gambar 2. Diagram Peningkatan Kompetensi Paedagogik Guru Tiap Siklus 


\section{KESIMPULAN}

Berdasarkan hasil analisis dan pembahasan hasil penelitian dapat kesimpulan sebagai berikut:

1. Kemampuan guru kelas SDI Wairhek Kecamatan Talibura Kabupaten Sikka, dalam mengikuti langkah-langkah prosedur menyusun RPP tematik yang mengacu pada Permendiknas No. 41 Tahun 2007 tentang standar proses dapat ditingkatkan melalui supervisi akademik. Hal ini terbukti dari kondisi awal sebesar 29,17\% (kategori sangat kurang) menjadi 68,75\% (kategori cukup) diakhir siklus I dan menjadi 84,38\% diakhir siklus II.

2. Kemampuan guru kelas SDI Wairhek Kecamatan Talibura Kabupaten Sikka dalam menyusun RPP tematik meningkat melalui proses supervisi akademik yang dilakukan disesuaikan dengan karakteristik guru dan diawali melalui proses pembinaan, dan pelatihan dengan rekan sejawat. Hal ini terbukti dari kondisi awal 57,74 (kategori Cukup) menjadi 75,00 (dengan kriteria Baik), dan meningkat menjadi 89,29 diakhir siklus II.

Berdasarkan kesimpulan di atas, maka dapat diajukan saran sebagai berikut.

a. Agar semua guru hendaknya mengikuti prosedur dalam penyusunan RPP tematik, karena RPP yang disusun dengan baik merupakan pedoman bagi guru dalam melaksanakan pembelajaran dengan baik juga.

b. Agar gur-guru memanfaatkan Kelompok Kerja Guru (KKG) di tingkat sekolah maupun KKG tingkat kecamatan masing masing sebagai wahana peningkatan kemampuan profesional sehingga dapat meningkatkan kemampuan dan keterampilannya dalam melaksanakan proses pembelajaran yang insfiratif, inovatif, menantang dan menyenangkan.

C. Bagi kepala sekolah, hendaknya secara rutin melaksanakan supervisi akademik agar dapat meningkatkan kualitas dan profesionalisme guru maupun kepala sekolah itu sendiri. 


\section{DAFTAR PUSTAKA}

Arikunto, S. 2011. Prosedur Penelitian: Suatu Pendekatan Praktik. Jakarta: Rineka Cipta.

Badan Standar Nasional Pendidikan. ( 2007 ), Standar Isi, Direktorat Pendidikan, Jakarta.

(2007), Standar proses, Direktorat Pendidikan, Jakarta

Depdikbud (1998) Keputusan Menteri Negara Pendayagunaan Aparatur Negara Tentang Jabatan Fungsional Pengawas Sekolah dan Angka Kreditnya, Dirjen Pendasmen, Jakarta . (2008) Pedoman Penelitian Tindakan Sekolah Peningkatan Kompetensi Supervisi Pengawas Sekolah SMA/SMK, Dirjen PMPTK Jakarta

Imron, Ali. (2000). Pembinaan Guru Di Indonesia. Malang: Pustaka Jaya.

Mukhtar dan Iskandar. 2009. Orientasi Baru Supervisi Pendidikan. Jakarta: GP Press.

Permendiknas (2007). Standar Kepala Sekolah/Madrasah. Jakarta.

Rusman, 2011, Model-Model Pembelajaran Mengembangkan Profesionalisme Guru, Jakarta, PT. Rajag Grafindo Persada.

Siti Aminah (2010), Kepala Sekolah Sebagai Supervisor Terhadap Kinerja Guru, dalam Media Sekolah, Edisi 57 Tahun III.

Trianto (2009) Pengembangan Model pembelajaran Temati, Prestasi Pustakaraya Jakarta

http://www.majalahpendidikan.com/2011/04/peran-kepala-sekolah-sebagaisupervisor 